\section{SINHALESE FAMILY WITH HAEMOGLOBIN S}

BY

\section{C. DE SILVA, M.D., F.R.C.P.}

D. T. D. BULUGAHAPITIYA, M.B., B.S. JUSTIN DE SILVA

Department of Paediatrics, University of Ceylon, Colombo

R. L. WICKREMASINGHE, Ph.D.

Medical Research Institute, Colombo

AND

J. H. P. JONXIS, M.D.

Department of Paediatrics, University of Groningen, Netherlands

Wickremasinghe, Ikin, Mourant, and Lehmann (1962) have reported haemoglobin $S$ in three unrelated families in a village in the Eastern Province approximately 30 miles $(48 \mathrm{~km}$.) from the village in which the family investigated here lives.

Three of us have been investigating all cases of thalassaemia and other haemoglobinopathies (Hb E thalassaemia) and their families since 1955 by electrophoresis, column chromatography, sickling, and alkali denaturation tests. No instance of the occurrence of the sickle-cell gene had been discovered by us until the present case (de Silva et al., 1959). One of us (J. de S.) had done the sodium metabisulphite test for sickling in over 150 specimens of blood from a random selection of cases of all types of anaemia seen in patients under the care of another of us (C. C. de S.) with no positive findings.

Wickremasinghe and Ponnuswamy (1962) investigated over 2,000 specimens of blood from Sinhalese for haemoglobin $\mathrm{S}$ without any positive findings.

In India, haemoglobin $S$ was first recorded by Lehmann and Cutbush (1952) among the aborigine tribes of the Nilgiri Hills. Subsequently haemoglobin $S$ has been reported from Orissa and Bihar, Uttar Pradesh and Madhya Pradesh, and Western India (Chatterjea, 1959). It is very unlikely that our families showing haemoglobin $\mathrm{S}$ are related to any of these in India, but it is a historical fact that Kaffir regiments had been imported into Ceylon from the sixteenth century onwards by the Portuguese, Dutch, and British rulers. It is difficult to ascertain from which part of Africa the constituents of these regiments originated. Quite tentatively we would suggest that the Portuguese and the Dutch probably obtained their recruits from the west and the British from the east side of Africa. Batticaloa, an old Dutch fort, is within 30 miles $(48 \mathrm{~km}$.) of the two villages where haemoglobin $S$ has been reported by Wickremasinghe and by the present authors, and it is more than likely that some African ancestors might have been responsible for the presence of haemoglobin $\mathrm{S}$ in these families.

Methods of Investigation.-(1) Paper electrophoresis -Whatman, $3 \mathrm{~mm}$. paper, 0.1 ; veronal buffer, $p H$ 8.6.

(2) Alkali denaturation test (Singer et al., 1951).

(3) Sickling-sodium metabisulphite method. (4) Haemoglobin estimation by the cyanhaematin method (venous blood).

\section{Case Report}

A Sinhalese girl aged 7 years from the Eastern Province of the island was admitted to Lady Ridgeway Hospital, Colombo, under the care of one of us (C. C. de S.) on October 28, 1960. The parents had noticed that the child was becoming more and more anaemic and dyspnoeic, as well as presenting a lump on the left side of the abdomen. for three years prior to admission. As the treatment for the anaemia given at the local district hospital during this period was without any benefit, she was referred for treatment to the Children's Hospital, Colombo.

On admission the child appeared undernourished and short for her age. Her weight was $28 \mathrm{lb}$. $(12.7 \mathrm{~kg}$.) and her height $39 \frac{1}{2}$ in. $(100.3 \mathrm{~cm}$.). She was grossly anaemic. There was no visible icterus. The lymph nodes were not palpable. Her heart was enlarged, the apex beat being in the fifth left intercostal space in the mid-clavicular line. A soft blowing systolic murmur was heard over the praecordium. The murmur was loudest at the base, but it was not conducted to the neck or to the axilla. The respiratory and central nervous systems were clinically normal. The liver was palpable 2 in. $(5 \mathrm{~cm}$.) below the right costal margin in the right hypochondrium and the spleen approximately $3 \frac{1}{2}$ in. $(8.9 \mathrm{~cm}$.) below the left costal margin. There were no ascites or leg ulcers present.

Her haemoglobin was 4.2 g./100 ml., red blood cells 1,440,000/c.mm., mean corpuscular volume 92 cubic microns, and mean corpuscular haemoglobin concentration $31 \%$. The packed cell volume was $13 \%$, and the reticulocytes $8.2 \%$. The red-cell fragility ranged from $0.4 \%$ to $0.1 \%(\mathrm{NaCl})$ (Table I). The white-blood-cell count was 9,400 (polymorphs $72 \%$, lymphocytes $24 \%$. myelocytes $4 \%$ ); 142 normoblasts were seen per 100 white blood cells. The blood film showed target cells and pessary forms with marked poikilocytosis and anisocytosis. The blood group was $\mathrm{O}$ with genotype $\mathrm{CDe} / \mathrm{CDe}$. The direct Coombs test was negative. Thick and thin blood films were repeatedly found to be negative for malarial parasites.

Haemoglobins S, F, and A were found in the blood by paper electrophoresis, sickling, and the alkaline denaturation test. This was confirmed by paper chromatography, starch electrophoresis, and iron-exchange chromatography.

Table I.-Patient's Blood Findings During Stay in Hospital

\begin{tabular}{|c|c|c|c|c|c|c|c|c|c|}
\hline Date & $\begin{array}{l}\text { Vol. of Blood } \\
\text { Transfused }\end{array}$ & $\underset{(\mathrm{g} . / 100 \mathrm{ml} .)}{\mathrm{Hb}}$ & $\begin{array}{l}\text { R.B.C. } \\
\text { per c.mm. }\end{array}$ & $\begin{array}{l}\text { P.C.V. } \\
(\%)\end{array}$ & M.C.V. & M.C.H.C. & $\begin{array}{c}\text { Reticulocytes } \\
(\%)\end{array}$ & $\begin{array}{c}\text { Normoblasts } \\
\text { per } 100 \text { W.B.C. }\end{array}$ & $\begin{array}{l}\text { Target } \\
\text { Cells }\end{array}$ \\
\hline $\begin{array}{r}29 ! 10^{\prime} 60 \\
1 / 11 / 60\end{array}$ & $28 \overline{\mathrm{ml}}$. & $\frac{4 \cdot 2}{-}$ & $1,440,000$ & 13 & $\underline{92}$ & 31 & $8 \cdot 2$ & 142 & $\stackrel{+}{+}$ \\
\hline $\begin{array}{l}14 / 11 / 60 \\
22 / 11 / 60 \\
23 / 1 / 60\end{array}$ & (Packed cells) & $\begin{array}{l}6.4 \\
3.7 \\
-\end{array}$ & $\begin{array}{c}2,140,000 \\
=\end{array}$ & $\begin{array}{l}20 \\
13 \\
-\end{array}$ & $\frac{84}{-}$ & $\begin{array}{l}27 \\
29 \\
-\end{array}$ & $\frac{2.8}{=}$ & $\bar{z}$ & $\begin{array}{l}+ \\
+\end{array}$ \\
\hline $\begin{array}{r}30 / 11 / 60 \\
6 / 12 / \epsilon 0\end{array}$ & $240 \mathrm{ml}$. & $6 \cdot 2$ & $2,030,000$ & 19 & 95 & 31 & $3 \cdot 8$ & $=$ & + \\
\hline $\begin{array}{c}9 / 12 / 60 \\
\text { Readmission }\end{array}$ & (racked cells) & $9 \cdot 8$ & $3,680,000$ & 34 & 95 & 29 & 0.4 & - & + \\
\hline $\begin{array}{c}3 / 3161 \\
10 / 3 / 61\end{array}$ & $\begin{array}{l}20 \overline{\mathrm{ml}} \text {. } \\
\text { (Packed cells) }\end{array}$ & 6.4 & $2,160,000$ & - & - & - & $2 \cdot 4$ & 424 & $\begin{array}{c}42 \cdot 2 \% \\
+\end{array}$ \\
\hline $13 / 3 / 61$ & (1 auken & 8.6 & $3,140,000$ & 29 & 94 & 31 & $2 \cdot 2$ & - & + \\
\hline
\end{tabular}


The -child was in hospital for 43 days and during this time she had several periods of mild pyrexia and a severe one of remittent fever-103-104 $4^{\circ}$ F. $\left(39.4-40^{\circ}\right.$ C.)-which occurred two weeks after admission and lasted for five days. The latter responded to treatment with penicillin and streptomycin. She had three blood transfusions $-280 \mathrm{ml}$. on November $1,240 \mathrm{ml}$. on November 23, and $250 \mathrm{ml}$. on December 6-and was sent home on December 10.

She was readmitted on March 3, 1961, and was found to be severely anaemic, with haemoglobin $6.4 \mathrm{~g} . / 100 \mathrm{ml}$., red blood cells $2,160.000 / \mathrm{c}$, mm., and reticulocytes $2.4 \%$. Her white-cell count totalled $5.400 / \mathrm{c} . \mathrm{mm}$., and there were 424 normoblasts (mostly polychromatophilic) per 100 W.B.C. in her peripheral blood. Her target cells now totalled $42.2 \%$. The spleen was more enlarged and almost reached the symphysis pubis. Her weight was $1 \mathrm{lb}$. $(0.45 \mathrm{~kg}$.) higher at $29 \mathrm{lb}$. $(13.2 \mathrm{~kg}$.) than on the previous admission.

\section{Discussion}

We investigated three generations of the present family (see Family Tree). The paternal grandmother
III 3 now aged 60 was found to be a sickler with $35.9 \%$ $\mathrm{Hb} \mathrm{S}, 3.3 \% \mathrm{Hb} \mathrm{F}$, and $2.8 \% \mathrm{Hb} \mathrm{A}_{2}$ (Table II). A male cousin of hers (III 1) through the maternal side showed $25.3 \% \mathrm{Hb} \mathrm{E}$; neither of these showed any signs of anaemia though the latter had a palpable liver and muddy sclerotics and gave a history of chronic alcoholism.

III 3 was twice married. By her first marriage she had three sons and two daughters (IV 1, 3, 5, 7, 10). The eldest daughter (IV 1) was a sickler with $39.8 \%$ $\mathrm{Hb} \mathrm{S}, 2.1 \% \mathrm{Hb} \mathrm{F}$, and $1.6 \% \mathrm{Hb} \mathrm{A}_{2}$. She has two children, a girl aged 10 years (V 1) who is a sickler with $44.7 \% \mathrm{Hb} \mathrm{S}$ and a boy aged 5 years (V 2) with no $\mathrm{Hb} \mathrm{S}$ but with $2.6 \% \mathrm{~A}_{2}$, which is within normal limits at this age. None of these patients showed any signs of illness. The eldest and youngest of the three sons of III 3 and their families had left the village and their whereabouts could not be ascertained.

The second son (IV 5) of III 3 is the father of the propositus. His blood showed $39.4 \% \mathrm{Hb} \mathrm{S}$ and the rest

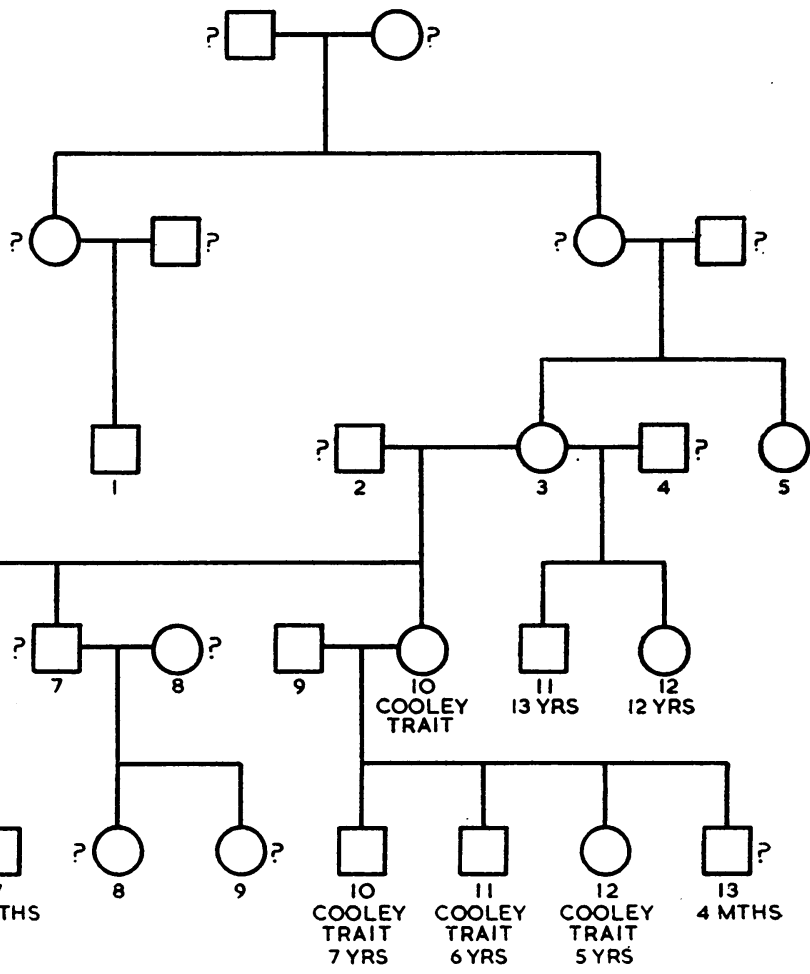

Family tree of a Sinhalese family with haemoglobin S. ? Denotes not investigated.

TABLE II.-Blood Findings in Other Members of Family

\begin{tabular}{|c|c|c|c|c|c|c|c|c|c|c|}
\hline $\begin{array}{l}\text { Ref. } \\
\text { No. }\end{array}$ & $\begin{array}{l}\text { Relationship to } \\
\text { Propositus }\end{array}$ & $\begin{array}{c}\text { Total } \mathrm{Hb} \\
\text { (g. } 100 \mathrm{ml} \text { ) }\end{array}$ & $\underset{(\%)}{\mathbf{H b}} A$ & $\underset{(\%)}{\operatorname{Hb}} S$ & $\underset{(\%)}{H b} F$ & $\underset{(\%)}{\mathrm{Hb}} \mathrm{A}_{2}$ & $\underset{(\%)}{\mathrm{Hb}} \mathrm{E}$ & $\begin{array}{l}\text { Fragility } \\
(\mathrm{NaCl})\end{array}$ & Sickling & $\begin{array}{l}\text { Blood } \\
\text { Film }\end{array}$ \\
\hline $\begin{array}{l}\text { V } 6 \\
\text { IV } 5 \\
\text { IV } 6 \\
\text { V } 5 \\
\text { V } 7 \\
\text { III } 3 \\
\text { III } 1\end{array}$ & $\begin{array}{l}\text { Propositus } \\
\text { Father } \\
\text { Mother } \\
\text { Brother } \\
\text { Pa } \\
\text { Paternal grandmother } \\
\text { Maternal first cousin } \\
\text { of grandmother }\end{array}$ & $\begin{array}{c}4 \cdot 2 \\
9 \cdot 4 \\
8 \cdot 6 \\
8 \cdot 9 \\
9 \cdot 4 \\
7 \cdot 8 \\
\text { Not done }\end{array}$ & $\begin{array}{l}34 \cdot 9 \\
60 \cdot 6 \\
96 \cdot 7 \\
98 \cdot 3 \\
97 \cdot 5 \\
58 \\
74 \cdot 8\end{array}$ & $\begin{array}{c}54 \cdot 4 \\
39 \cdot 4 \\
= \\
\overline{35 \cdot 9} \\
=\end{array}$ & $\begin{array}{l}10 \cdot 7 \\
= \\
\bar{z} \\
=\end{array}$ & $\begin{array}{l}\overline{-} \\
\overline{3 \cdot 3} \\
1 \cdot 7 \\
2 \cdot 5 \\
2 \cdot 8 \\
-\end{array}$ & $\begin{array}{l}\bar{z} \\
\bar{z} \\
25 \cdot 3\end{array}$ & $\begin{array}{l}0.4-0.10 \\
0 \cdot 35-0 \cdot 10 \\
0 \cdot 5-0.35 \\
0 \cdot 4-0 \cdot 20 \\
0.5-0.05 \\
0.5-0 \cdot 20 \\
-\end{array}$ & $\begin{array}{l} \pm \\
\pm \\
\pm \\
\pm \\
+\end{array}$ & $\begin{array}{l}\mathrm{Nt}+\mathrm{TC}+ \\
\mathrm{TC} \text { and }+ \\
\text { TC+ } \\
\text { TC and } \mathrm{P}+ \\
\text { TC+ } \\
\text { Normal } \\
\quad,\end{array}$ \\
\hline $\begin{array}{l}\text { III } 5 \\
\text { IV } 10 \\
\text { IV } 1 \\
\text { IV } 12\end{array}$ & $\begin{array}{l}\text { Paternal grand-aunt } \\
\text { Paternal aunt } \\
\text { Paternal grandmother's } \\
\text { child by second }\end{array}$ & $\begin{array}{l}9 \cdot 6 \\
7.8 \\
8.8\end{array}$ & $\begin{array}{l}97 \cdot 8 \\
98 \cdot 3 \\
56 \cdot 5\end{array}$ & $\frac{\overline{3}}{39 \cdot 8}$ & $\frac{2 \cdot 2}{2 \cdot 1}$ & $\begin{array}{l}\overline{1.7} \\
1.6\end{array}$ & $=$ & $\frac{\bar{Z}}{0.4-0.15}$ & $\bar{t}$ & $\begin{array}{l}\mathrm{Nt}+ \\
\text { TCt+ } \\
\text { Normal }\end{array}$ \\
\hline $\begin{array}{ll}\text { IV } & 11 \\
\text { V } & 11 \\
\text { V } & 10 \\
\text { V } & 1\end{array}$ & $\begin{array}{l}\text { hust and } \\
\text { Father's sister'’ son } \\
\text { Father's sister's } \\
\text { daughter }\end{array}$ & $\begin{array}{l}8 \cdot 8 \\
9 \cdot 2 \\
8 \cdot 4 \\
5 \cdot 9 \\
9 \cdot 2\end{array}$ & $\begin{array}{l}60 \cdot 6 \\
56 \cdot 9 \\
97 \cdot 0 \\
97 \cdot 2 \\
55 \cdot 3\end{array}$ & $\begin{array}{l}39 \cdot 4 \\
\frac{43 \cdot 1}{7} \\
\frac{4}{4} \cdot 7\end{array}$ & $\begin{array}{l}\bar{z} \\
\bar{z}\end{array}$ & $\begin{array}{l}\bar{Z} \\
3 \cdot 0 \\
2 \cdot 8 \\
-\end{array}$ & $\begin{array}{l}\bar{z} \\
\bar{z}\end{array}$ & $\begin{array}{l}0.5-0.15 \\
0.35-0.15 \\
0.45-0.25 \\
0.45-0.20\end{array}$ & $\begin{array}{l}+ \\
+ \\
+ \\
+\end{array}$ & $\begin{array}{l}\text { TC+ } \\
\text { Normal } \\
\text { TC̈+ } \\
\text { Normal }\end{array}$ \\
\hline $\begin{array}{l}\mathrm{V} 12 \\
\mathrm{~V} 2\end{array}$ & Father's sistei"s son & $\begin{array}{l}9 \cdot 4 \\
8 \cdot 6\end{array}$ & $\begin{array}{l}96 \cdot 9 \\
97 \cdot 4\end{array}$ & 二 & 二 & $\begin{array}{l}3 \cdot 1 \\
2 \cdot 6\end{array}$ & 二 & $\underline{0.5-0.30}$ & - & ," \\
\hline
\end{tabular}


was only $\mathrm{Hb} \mathrm{A}$, while his wife (IV 6) who was not related to him showed $3.3 \% \mathrm{Hb} \mathrm{A}_{2}$ in her blood and was therefore classified as a Cooley trait. There are two boys (V 5 and 7) from this marriage. Each of them showed traces of $\mathbf{H b ~} \mathrm{A}_{2}$ in their bloods, but these are within normal limits.

The daughter is the propositus, and showed $54.4 \%$ of $\mathrm{Hb} \mathrm{S}$ and $10.7 \%$ of $\mathrm{Hb} \mathbf{F}$ and is clinically a case of $\mathrm{Hb} \mathrm{S}$ thalassaemia disease or drepanocytic anaemia.

The youngest daughter (IV 10) of III 3 shows $1.7 \%$ of $\mathrm{Hb} \mathrm{A}_{2}$ and her husband is normal, but three of her children whose bloods were investigated showed excess of $\mathrm{Hb} \mathrm{A}_{2}$ (V 10,11, and 12). We were not allowed to investigate the blood of the youngest male infant aged 4 months (V 13).

The findings suggest that their mother (IV 10) was a carrier of the Cooley gene even though the level of the $\mathrm{Hb} \mathrm{A}_{2}$ discovered in her blood was within normal limits $\left(A_{2}=1.7 \%\right)$. The grandmother of the propositus (III 3) by her second marriage has produced two sicklers, a girl aged 12 years (IV 12) with $39.4 \% \mathrm{Hb} \mathrm{S}$ and a boy aged 13 (IV 11) with $43.1 \% \mathrm{Hb} \mathrm{S}$. They were not anaemic on inspection (Hb 8.8 and 9.2 g./ $/ 100 \mathrm{ml}$.), but both of them showed signs of vitamin-A deficiency in their eyes.

\section{Summary}

The interest in this family lies in the following facts.

It has shown the sickle-cell gene in three generations of a family in which 17 members were investigated. We were not able to investigate generations I and II. Only the propositus, who had $\mathrm{Hb} \mathrm{F}$ as well as $\mathrm{Hb} \mathrm{S}$ in excess, was clinically affected.

One of the members (III 1) showed a $\mathrm{Hb} \mathrm{E}$ trait. His family was not available for further investigation.

$\mathrm{Hb} \mathrm{F}$ was shown in excess only in the propositus and her paternal grandmother.

$\mathrm{Hb} \mathrm{A}_{2}$ or the Cooley gene was found in five members, including the mother and paternal grandmother as well as in all three children of the paternal aunt of the propositus (V 10, 11, and 12). The mother of these children, however, only showed $1.7 \% \mathrm{Hb} \mathrm{A}_{2}$, which is well within normal limits. Two brothers of the patient showed only small traces of $\mathrm{Hb} \mathrm{A}_{2}$ in their blood.

\section{REFERENCES}

Chatterjea, J. B (1959), In Abnormal Haemoglobins, p. 334, C.I.O.M S. Symposium. Blackwell, Oxford.

De Silva, C. C., Jonxis, J. H. P., and Wickremasinghe, R. L. (1959). Ibid., p. 340.

Lehmann, H., and Cutbush, M. (1952). Brit. med. J., 1, 404

Singer, K., Chernoff, A. J., and Singer, L. (1951). Blood, 6, 413

Wickremasinghe, R. L. Ikin, Elizabeth W., Mourant, A. E., and Lehmann, H. (1962). J. Roy. anthrop. Soc. In press.

and Ponnuswamy, N. E. L. (1962). Spolia Zeylandica. In press.

The Medical Officer of Health, Stockport, has issued the fifth edition of the handbook "A Guide to the Health Services of Stockport." It is in three sections. Section I outlines the services provided by and under the direct administration of the local health authority. The hospital and specialist services administered by the Stockport and Buxton Hospital Management Committee on behalf of the Manchester Regional Hospital Board are described in Section II. The following services are directly administered by the Board: tuberculosis, venereal diseases. laboratory services, and mass miniature radiography. A brief description of the general medical practitioner, dental, pharmaceutical, and ophthalmic services is contained in Section III.

\section{COMBINATIONS OF HIGH LEVELS OF} HAEMOGLOBIN F WITH HAEMOGLOBINS A, S, AND C IN GHANA

\author{
BY
}

G. R. THOMPSON, M.B., M.R.C.P., D.T.M.\&H.

Captain, R.A.M.C.; Junior Specialist in Medicine, Queen Alexandra Military Hospital, London

AND

\section{H. LEHMANN, M.D., Sc.D., M.R.C.P., F.R.I.C Reader in Chemical Pathology, St. Bartholomew's Hospital, London}

From Ghana came the first report of the existence of a benign condition in which haemoglobin $S$ together with a high level of foetal haemoglobin persists into adult life (Edington and Lehmann, 1955a). The two subjects concerned were originally thought to be adult sickle-cell homozygotes, but family studies showed that their high levels of foetal haemoglobin were transmitted to their children independently of haemoglobin $S$ (Edington and Lehmann, 1955b). Although in both propositi haemoglobin $\mathrm{S}$ was the major component, they appeared fit and exhibited neither microcytosis nor anaemia. This was in direct contrast to other conditions in which a mixture of haemoglobins $\mathrm{S}$ and $\mathrm{F}$ may be foundnamely, sickle-cell disease and sickle-cell thalassaemia. Similar reports of subjects showing persistence of haemoglobin $\mathrm{F}$ in combination with haemoglobin $\mathrm{A}$ or $\mathrm{S}$ came from Uganda (Jacob and Raper, 1958) and Jamaica (Went and MacIver, 1958), and the absence of any of the morphological stigmata of classical thalassaemia was noted by these workers. Lehmann (1959) termed the condition non-microcythaemic thalassaemia, but this description failed to get official recognition (British Medical Journal, 1960). There have been full reviews of the now considerable number of observations of this condition by Rucknagel and Neel (1961), Bradley, Brawner, and Conley (1961), and Huisman (1962).

Comparable combinations between haemoglobins $\mathrm{C}$ and $\mathrm{F}$ were reported from America by Kraus, Koch, and Burckett (1961) and Schneider, Levin, and Everett (1961), and from Jamaica by MacIver, Went, and Irvine (1961).

The present paper is concerned with two families in Accra whose members demonstrate combinations of haemoglobins $S$ and $F$ in one instance, of haemoglobins $\mathrm{C}$ and $\mathrm{F}$ in another, and of $\mathrm{A}$ and $\mathrm{F}$ in several.

\section{Methods}

Venous blood was obtained from all the subjects concerned and submitted to paper electrophoresis and alkali denaturation. Electrophoresis was performed in hanging strip tanks on Whatman No. 1 paper using barbitone buffer at $p \mathbf{H}$ 8.8. Alkali denaturation was performed using the one-minute method of Singer, Chernoff, and Singer (1951). The presence of haemoglobin $\mathrm{S}$ was confirmed where indicated by sickling tests, using $2 \%$ sodium metabisulphite (Daland and Castle, 1948). Leishman-stained thin blood films were examined for evidence of microcytosis and target cells. Haemoglobin concentrations were determined with a photoelectric colorimeter. Haemoglobin $\mathrm{A}_{2}$ levels were 